\title{
Heterotrophic nanoflagellate and ciliate bacterivorous activity and growth in the northeast Atlantic Ocean: a seasonal mesoscale study
}

\author{
Hera Karayanni ${ }^{1,2,3, *}$, Urania Christaki ${ }^{2,4}$, France Van Wambeke ${ }^{1}$, \\ Melilotus Thyssen ${ }^{1}$, Michel Denis ${ }^{1}$
}

${ }^{1}$ Laboratoire de Microbiologie, Géochimie et Ecologie Marines, UMR 6117, CNRS, Université de la Méditerranée, Campus de Luminy, case 901, 13288 Marseille Cedex 9, France

${ }^{2}$ Hellenic Centre for Marine Research, PO Box 712, 19013 Anavissos, Greece

${ }^{3}$ Present address: Department of Ichthyology \& Aquatic Environment, School of Agricultural Sciences, University of Thessaly, 38446 Nea Ionia, Greece

${ }^{4}$ Present address: Laboratoire d'Océanologie et de Géosciences, CNRS, UMR LOG 8187, Université du Littoral Côte d'Opale (MREN), 32 avenue Foch, 62930 Wimereux, France

\begin{abstract}
The grazing effect of heterotrophic nanoflagellates (HNF) and ciliates on bacterial production (BP), as well as their growth rates, was studied in winter, spring and autumn 2001 during the French research project Programme Océan Multidisciplinaire Méso-Echelle (POMME) in the northeast Atlantic Ocean ( 38 to $45^{\circ} \mathrm{N}, 16$ to $22^{\circ} \mathrm{W}$ ). The variability of different parameters studied appears to be largely controlled by the seasonal and latitudinal gradients of primary production rather than the strong eddy activity at the mesoscale level in the area. Heterotrophic microbial abundance, biomass and protistan grazing varied temporally, presenting highest values during the phytoplankton bloom, during the spring period and following the northward propagation of the bloom. HNF biomass integrated over the upper $100 \mathrm{~m}$ was highest in spring (270 to $850 \mathrm{mg} \mathrm{C} \mathrm{m}^{-2}$ ). Ciliate integrated bio-

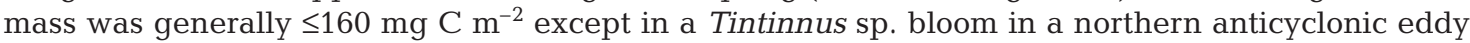
(A1) in spring when it reached $637 \mathrm{mg} \mathrm{C} \mathrm{m}^{-2}$. HNF and ciliate growth rates varied from 0.2 to $0.7 \mathrm{~d}^{-1}$ and 0.2 to $1.4 \mathrm{~d}^{-1}$, respectively. The fraction of BP consumed by ciliates was generally $<10 \%$ except in the anticyclonic eddy A1 in spring during a tintinnid bloom when it reached $37 \%$ of BP. In conclusion, our data revealed that HNF can remove a large fraction of bacterial production in the northeast Atlantic Ocean (83 $\pm 27 \%$, average of all sampling sites and seasons). Ciliates transferred less carbon to higher trophic levels than did HNF; however, episodic high occurrence of large bacterivorous ciliates, primarily tintinnids, increased the role of theses organisms as C-links in the microbial food web.
\end{abstract}

KEY WORDS: Heterotrophic nanoflagellates · Ciliates · Tintinnids · Bacterivory · Ingestion rates · Growth rates · Atlantic Ocean

\section{INTRODUCTION}

Heterotrophic bacteria, a crucial component of marine food webs, are predominant in the transformation and mineralization of dissolved organic carbon (DOC). Recent models based on large scale oceanic data have shown that the ratio between bacterial and primary production ranges from 2 to $10 \%$ in the cold and temperate climate zones, to $40 \%$ in the oligotrophic equatorial regions (Hoppe et al. 2002). It is, therefore, an important step towards the establishment of biogeochemical models within oceanic ecosystems that the amount of carbon that flows through bacterial grazers (protists) is accurately quantified.

The quantity of bacterial carbon channeled to higher trophic levels is a function of both foodweb structure 
and the conversion efficiencies of the grazers. Numerous studies have shown that small heterotrophic nanoflagellates are the dominant consumers of bacteria in different aquatic systems. We now know that a significant part of bacterioplankton production (BP) is grazed by flagellates 2 to $20 \mu \mathrm{m}$ in size (Fenchel 1982, Vaqué et al. 1992, Christaki et al. 2001). The interposition of a series of smaller grazers between bacteria and the mesozooplankton results in the dissipation of large amounts of bacterial carbon. Seemingly, ciliate bacterivory represents a shortcut between bacteria and higher consumers. A microbial foodweb model established by Ducklow (1991) showed that the amount of BP transferred to mesozooplankton is twice as important when it is directly ingested by ciliates and passes from 5 to $13 \%$.

Ciliate ingestion of particles $<2 \mu \mathrm{m}$ has been demonstrated in laboratory experiments (e.g. Fenchel 1980). Ciliate bacterivory in situ has been well documented in freshwaters where small species (mostly $<30 \mu \mathrm{m}$ ) numerically dominate ciliate communities (Šimek et al. 1995). The studies documenting individual ciliate bacterivory in marine waters are scarce and deal mainly with coastal (e.g. Sherr et al. 1989) or estuarine waters (e.g. Vaqué et al. 1992); while the percent of BP ingested directly by larger protists has rarely been estimated (Rivkin et al. 1999, Christaki et al. 2001, Vaqué et al. 2002). These authors have measured the consumption of bacteria by protists based on disappearance of fluorescently labeled bacteria (FLB) over long time incubations ( 24 to $48 \mathrm{~h}$ ) or with the dilution technique in size-fractionated seawater. Neither of these methods permits the measurement of the grazing effect of individual consumers. Also, to the best of our knowledge, no study exists estimating the percentage of BP ingested by ciliates based on the individual ciliate uptake of bacteria in oceanic waters. Finally, information on growth rates of natural assemblages of protists is scarce (Verity et al. 1993, Neuer \& Cowles 1994) mainly because of the absence of a direct method of measurement and the inconvenience of the indirect methods (Gifford \& Caron 2000).

The present study was conducted within the framework of the French research project Programme Océan Multidisciplinaire Méso-Echelle (POMME), designed to investigate the coupling of dynamical and biological processes in the northeast Atlantic Ocean, with an emphasis on the role of modal waters on the export of biogenic matter (www.lodyc.jussieu.fr/POMME/). Until now, Maixandeau et al. (2005) have shown that small organisms (picoautotrophs, nanoautotrophs and bacteria) are the main organisms contributing to biological fluxes throughout the year. Additionally, according to net community production (NCP) data, autotrophy dominates in winter and spring, while a balanced sys- tem prevails in autumn. Protist herbivory on Synechococcus, Prochlorococcus, pico- and nanoeukaryotes shows an important seasonal and spatial variability and could explain up to $94 \%$ of the consumption of the primary production in the area (Karayanni et al. 2005). The present study aims to provide additional information on the heterotrophic processes that influence carbon flow in the area, by quantifying the grazing effect of HNF and ciliates on BP as well as on their growth rates at the mesoscale level and on a seasonal scale (winter, spring and autumn).

\section{MATERIALS AND METHODS}

Study site and environmental conditions. Sampling was conducted from February to October 2001, with 3 oceanographic cruises on board the RVs 'Atalante' and 'Thalassa'. The sampling area was centered on $41.5^{\circ} \mathrm{N}$, $19^{\circ} \mathrm{W}$ in the northeast Atlantic Ocean between the Iberic Peninsula and the Azores Islands (Fig. 1). This area is characterized by a strong and well organized eddy activity at the mesoscale level. Measurements were made at 4 individual stations during winter (POMME 1, February to March), spring (POMME 2, April to May) and autumn (POMME 3, September to October). Each station was located in a different hydrological structure. These hydrological structures are defined by letters (A: anticyclonic eddy, C: cyclonic

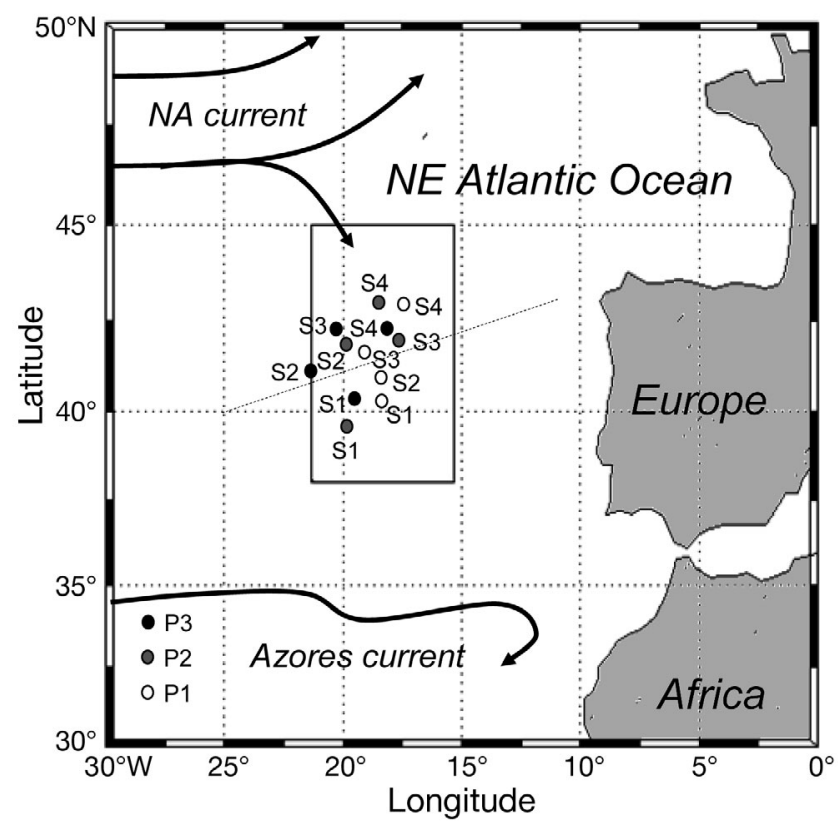

Fig. 1. Study area of the POMME project ( 38 to $45^{\circ} \mathrm{N}, 16$ to $22^{\circ} \mathrm{W}$ ) and the location of sampling sites (S1 to S4) during winter (P1), spring (P2) and autumn (P3) in 2001. For hydrological structures related to the stations, see Table 1 . The dashed line represents the winter mixed layer depth discontinuity zone 
eddy, FR: front, SP: saddle point) and by numbers for each new eddy (Table 1). The SP is an intermediate zone without any eddy activity, established between 4 mesoscale structures, 2 cyclonic and 2 anticyclonic eddies (L. Prieur pers. comm.). Three hydrological structures during POMME, one cyclonic (C4) and 2 anticyclonic eddies (A1 in the north and A2 in the south), persisted and were sampled during the different seasons while others were transient (Table 1).

A frontal structure at $41^{\circ} \mathrm{N}$ (Fig. 1) separated the study area into productive and oligotrophic waters in the north and the south, respectively. A clear increase in primary production was observed between winter and spring (Karayanni et al. 2005); however, the contribution of large diatoms to the phytoplankton bloom was generally low, except at the northern eddy A1 where a Pseudo-nitzschia sp. bloom was observed in spring (Karayanni et al. 2005 and references therein). Satellite derived data of surface ocean chlorophyll (SCHL) showed a northward propagation of the bloom in spring between March and May (Lévy et al. 2005). The mean temperature at $5 \mathrm{~m}$ was approximately $14^{\circ} \mathrm{C}$ in winter (P1) and spring (P2), while highest values were recorded in autumn $\left(\mathrm{P} 3,21^{\circ} \mathrm{C}\right)$. The mixed layer depth (Table 1) varied strongly between sampling sites reflecting their particular characteristics as well as the latitudinal variations (Maixandeau et al. 2005). The euphotic zone was relatively constant during P1 and P2 (40 to $60 \mathrm{~m}$ ) and reached over $80 \mathrm{~m}$ during P3 (Maixandeau et al. 2005).

Table 1. Hydrological structures, coordinates, sampling dates and mixed layer depth of different sites (S1, S2, S3 and S4) visited during the 3 POMME cruises in winter (P1), spring (P2) and autumn (P3) 2001. Different eddies are defined by letters and numbers. $\mathrm{A}=$ anticyclonic eddy, $\mathrm{C}=$ cyclonic eddy, $\mathrm{FR}=$ front, $\mathrm{SP}=$ saddle point. Numbers $(1,2,3$ and 4$)$ define the different eddies sampled during the cruises while letter $\mathrm{b}$ indicates that the sampling site was located at the boundary of the corresponding eddy. MLD = mixed layer depth (mean $\pm \mathrm{SD}$, $\mathrm{n}$ in parentheses)

\begin{tabular}{|ccccc|}
\hline & $\begin{array}{c}\text { Hydrological } \\
\text { structure }\end{array}$ & Coordinates & $\begin{array}{c}\text { Sampling } \\
\text { date }\end{array}$ & $\begin{array}{c}\text { MLD } \\
(\mathrm{m})\end{array}$ \\
\hline P1 & & & & \\
S1 & $\mathrm{A} 2$ & $40.1^{\circ} \mathrm{N}-18.7^{\circ} \mathrm{W}$ & $1 \mathrm{Mar}$ & $26 \pm 13(4)$ \\
S2 & $\mathrm{FR}$ & $41.1^{\circ} \mathrm{N}-18.6^{\circ} \mathrm{W}$ & $6 \mathrm{Mar}$ & $71 \pm 20(3)$ \\
S3 & $\mathrm{C} 4$ & $41.8^{\circ} \mathrm{N}-19.2^{\circ} \mathrm{W}$ & $10 \mathrm{Mar}$ & $48 \pm 16(3)$ \\
S4 & $\mathrm{A} 1$ & $43.3^{\circ} \mathrm{N}-17.4^{\circ} \mathrm{W}$ & $14 \mathrm{Mar}$ & $98 \pm 7(3)$ \\
P2 & & & & \\
S1 & $\mathrm{A} 2$ & $39.8^{\circ} \mathrm{N}-19.8^{\circ} \mathrm{W}$ & $17 \mathrm{Apr}$ & $21 \pm 6(4)$ \\
S2 & $\mathrm{C} 4$ & $41.9^{\circ} \mathrm{N}-19.7^{\circ} \mathrm{W}$ & $22 \mathrm{Apr}$ & $33 \pm 3(3)$ \\
S3 & $\mathrm{SP}$ & $42.1^{\circ} \mathrm{N}-17.7^{\circ} \mathrm{W}$ & $26 \mathrm{Apr}$ & $31 \pm 16(3)$ \\
S4 & $\mathrm{A} 1$ & $43.3^{\circ} \mathrm{N}-18.8^{\circ} \mathrm{W}$ & $1 \mathrm{May}$ & $61 \pm 5(3)$ \\
P3 & & & & \\
S1 & $\mathrm{A} 3$ & $40.1^{\circ} \mathrm{N}-19.1^{\circ} \mathrm{W}$ & $19 \mathrm{Sep}$ & $34 \pm 3(4)$ \\
S2 & $\mathrm{C} 4 \mathrm{~b}$ & $42.2^{\circ} \mathrm{N}-19.8^{\circ} \mathrm{W}$ & $23 \mathrm{Sep}$ & $39 \pm 5(3)$ \\
S3 & $\mathrm{C} 4$ & $41.5^{\circ} \mathrm{N}-22.0^{\circ} \mathrm{W}$ & $27 \mathrm{Sep}$ & $37 \pm 7(3)$ \\
S4 & $\mathrm{C} 3 \mathrm{~b}$ & $42.4^{\circ} \mathrm{N}-18.0^{\circ} \mathrm{W}$ & $2 \mathrm{Oct}$ & $39 \pm 5(3)$ \\
\hline
\end{tabular}

Ciliate, HNF and bacterial standing stocks. Sampling was always conducted at midday. For ciliate enumeration, 200 to $250 \mathrm{ml}$ samples were taken from the upper $100 \mathrm{~m}$ at 9 different depths $(5,10,20,30,40,50$, 60,80 and $100 \mathrm{~m}$ ) and fixed with acid Lugol's solution (final concentration $0.4 \%$ ). The samples were analyzed at 400× with an Olympus IX-70 inverted microscope. Ciliate abundances were converted into biomass using appropriate geometric formulae and a carbon conversion factor of $190 \mathrm{fg} \mathrm{C} \mathrm{mm}^{-3}$ (Putt \& Stoecker 1989). Details of the preceding protocol are described in Karayanni et al. (2004, 2005). Nanoflagellate samples (20 to $30 \mathrm{ml}$ ) were preserved with ice-cold glutaraldehyde (final concentration 1\%) and enumerated using an Olympus AX-70 PROVIS epifluorescence microscope at $1000 \times$ after staining with 4',6-diamidino-2phenylindole dihydrochloride (DAPI). Linear dimensions of HNF were measured and their biovolumes calculated (P1: $8.5 \mu^{3}$, P2: $14.6 \mu^{3}$, P3: $5.7 \mu^{3}$, Karayanni et al. 2005) considering an average equivalent spherical diameter for each cruise. A carbon-to-

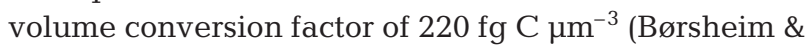
Bratbak 1987) was used to calculate HNF biomass.

Bacterial abundance was determined using flow cytometry as described by Thyssen et al. (2005). Prefiltered seawater (100 $\mu \mathrm{m}$ mesh size net) was preserved with $2 \%$ paraformaldehyde, frozen on board and stored in liquid nitrogen. Before analysis samples were thawed at room temperature and bacteria nucleic acids were stained to become fluorescent upon excitation with an air-cooled $488 \mathrm{~nm}$ argon laser. For staining, $1 \mathrm{ml}$ seawater subsamples were supplemented with $10 \mu \mathrm{l}$ SybrGreen II (from the Molecular Probes ${ }^{\circledR}$ solution diluted $1 / 5000$ in final solution) and incubated for $15 \mathrm{~min}$ in the dark. Samples were analyzed with a flow cytometer (Cytoron Absolute, ORTHO Diagnostic Systems) equipped with the $488 \mathrm{~nm}$ argon laser. Data were collected and stored in list mode with the Immunocount II software (ortho Diagnostic Systems) and cluster analyses were performed with the Winlist software (Verity Software House). Regions were established on cytogram plots of side scatter versus green fluorescence to define high nucleic acid (HNA) and low nucleic acid (LNA) bacterial cells. For conversion to carbon biomass, $15 \mathrm{fg} \mathrm{C} \mathrm{Cell}^{-1}$ was used (Caron et al. 1995). Integrated values of heterotrophic microbial biomass were calculated according to the trapezoid rule. 
Preparation of fluorescently labeled prey and grazing experiments. Fluorescently labeled bacteria (FLB) were prepared from cultures of Brevundimonas diminuta (formerly Pseudomonas diminuta) as described by Vázquez-Domínguez et al. (1999). Brevundimonas diminuta (provided by D. Vaqué) was cultured on Luria-Bertani agar and harvested after 2 to 3 wk of incubation at $19^{\circ} \mathrm{C}$ so that starved small-sized cells were obtained $(1.07 \mu \mathrm{m}$ length, $0.29 \mu \mathrm{m}$ width, $0.064 \mu^{3}$ volume; Vázquez-Domínguez et al. 1999). Approximately 30 colonies were suspended in $10 \mathrm{ml}$ of phosphate buffer saline (PBS) and sonicated at $60 \mathrm{~W}$ until bacterial aggregates were completely disrupted. Cells were harvested by centrifugation at $9500 \times g$ for $5 \mathrm{~min}$, resuspended in PBS, then incubated for $2.5 \mathrm{~h}$ at $60^{\circ} \mathrm{C}$ with 5-(4,6-dichlorotriazin-2-yl) aminofluorescein (DTAF) at a final concentration of $0.2 \mathrm{mg} \mathrm{ml}^{-1}$. The labeled suspensions were centrifuged and washed with PBS to clear discoloration of the DTAF. For the last washing step, seawater filtered on $0.2 \mu \mathrm{m}$ pore-size filters was used. FLB, at the concentration of $10^{8}$ cells $\mathrm{ml}^{-1}$, were stored in $1 \mathrm{ml}$ aliquots at $-20^{\circ} \mathrm{C}$ until used.

To study protist grazing on bacteria, $1.2 \mathrm{l}$ water samples were inoculated with FLB at 'tracer' concentrations $\left(10^{4} \mathrm{FLB} \mathrm{ml}^{-1}, \leq 10 \%\right.$ of natural bacterial abundance). FLB were sonicated for 2 to 3 min prior to addition, which provided sufficient time for them to completely disperse. Samples for ciliate $(250 \mathrm{ml})$ and nanoflagellate $(20 \mathrm{ml})$ vacuole content analysis were removed initially at time $=0\left(t_{0}\right)$ and after 15 and $30 \mathrm{~min}$. Ciliate samples were fixed immediately with $2 \%$ borated formalin and stored at $4{ }^{\circ} \mathrm{C}$ prior to analysis. FLB inside ciliates were enumerated at $400 \times$ with an Olympus IX-70 inverted microscope under blue light excitation. Loss of cells due to fixation with formalin was compensated for by applying a correction factor derived by counts of cells stained in Lugol's solution (Karayanni et al. 2004).

Nanoflagellate samples were fixed with $2 \%$ ice-cold glutaraldehyde, filtered onto $2 \mu \mathrm{m}$ black filters, stained with DAPI and stored at $-20^{\circ} \mathrm{C}$. Vacuole content was analyzed using an Olympus AX-70 Provis epifluorescence microscope at $1000 \times$ under blue light excitation. Grazing experiments were carried out near surface $(5 \mathrm{~m})$ and close to the in situ fluorescence maximum (40 to $60 \mathrm{~m}$ ) at all sites. Ingestion rates were obtained by multiplying FLB uptake by the ratio of bacteria abundances to the added FLB. For ingestion rate estimates, the 15 min incubation time was considered as adequate, because after $30 \mathrm{~min}$ the average number of FLB per predator was either constant or had already leveled off. Based on ingestion rates and protist abundances and considering a $15 \mathrm{fg} \mathrm{C}$ bacterium $^{-1}$ conversion factor (Caron et al. 1995), total carbon consump-

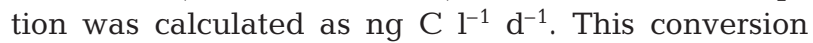

factor is intermediate compared with those adopted in previous studies conducted in the North Atlantic Ocean, the extremes being $7 \mathrm{fg} \mathrm{C}$ cell $^{-1}$ (Zubkov et al. 2000a) and $20 \mathrm{fg} \mathrm{C} \mathrm{cell}^{-1}$ (Ducklow et al. 1993).

HNF and ciliate growth rates. Protist growth rates were estimated in fractionated seawater incubations. In winter (P1), incubations were conducted only at the surface (5 m), while in spring (P2) and autumn (P3) they were conducted both at the surface $(5 \mathrm{~m})$ and at the maximum fluorescence depth (40 to $60 \mathrm{~m}$ ). For HNF, the water was filtered through a $10 \mu \mathrm{m}$ polycarbonate Nuclepore filter $(147 \mathrm{~mm})$ in a gravity filtration device (Bailey's Plastic Fabrication) to screen out larger organisms. The filtered water was then transferred in duplicate polycarbonate 21 bottles. For ciliates, seawater was gently screened through $64 \mu \mathrm{m}$. All bottles were placed in an on-deck incubator with circulating surface seawater under a screen at $50 \%$ in situ irradiance. Growth experiments lasted $48 \mathrm{~h}$ and samples for protist counting were taken at $24 \mathrm{~h}$ intervals.

Growth rate $\left(\mu \mathrm{d}^{-1}\right)$ was determined according to Frost (1972):

$$
\mu=\left(\ln \left[N_{t} / N_{0}\right]\right) / t
$$

where $N_{t}$ and $N_{0}$ are the number of cells at time $t$ and time 0 .

Protist production $\left(P, \mu \mathrm{g} \mathrm{Cl}^{-1} \mathrm{~d}^{-1}\right)$ was estimated as:

$$
P=B \times \mu
$$

where $B$ is the biomass $\left(\mu \mathrm{g} \mathrm{Cl} l^{-1}\right.$ ) and $\mu$ the growth rate (Eq. 1).

The carbon demand $\left(C D, \mu g \mathrm{Cl}^{-1} \mathrm{~d}^{-1}\right)$ was estimated as:

$$
\mathrm{CD}=P / Y
$$

where $P$ is the production (Eq. 2) and $Y$ the growth yield, equal to $40 \%$ (Ducklow 1983, Fenchel 1986).

Bacterial production. Bacterial production (BP) was measured at 8 (P1 and P2) or 9 (P3) different depths (5, $10,20,30,40,50,60,80$ and $100 \mathrm{~m}$ ) in the 0 to $100 \mathrm{~m}$ water column by ${ }^{3} \mathrm{H}$-leucine incorporation according to the microcentrifugation technique as described in Van Wambeke et al. (2002). At each depth, $1.5 \mathrm{ml}$ duplicate samples and a control were incubated with a mixture of L- $\left[4,5-{ }^{3} \mathrm{H}\right]$ leucine (Amersham, TRK 636, $160 \mathrm{Ci}$ $\mathrm{mmol}^{-1}$ ) and non-radioactive leucine, added at final concentrations of $7 \mathrm{nM}$ and $13 \mathrm{nM}$, respectively, and incubated in the dark at in situ temperature. After 2 to $4 \mathrm{~h}$, incubation was terminated by the addition of $200 \mu \mathrm{l}$ trichloracetic acid (5\% final concentration). Concentration and time kinetics were carried out during the different cruises. For time kinetics, incorporation of leucine with time was measured for up to $4 \mathrm{~h}$ at $5 \mathrm{~m}$ depth on 3 occasions ( 1 per cruise), and up to $9 \mathrm{~h}$ at $100 \mathrm{~m}$ depth (on one occasion during P3) and was 
found to be linear. Concentration kinetics were also carried out to check for isotopic dilution, with a set of concentrations added from 2 to $40 \mathrm{nM}(2,510,20$ and $40 \mathrm{nM})$. From the 4 concentration kinetics tested at $5 \mathrm{~m}$ depth (1 during P1, 1 during P2, 2 during P3), isotopic dilution (ID) factor with $20 \mathrm{nM}$ additions of leucine was $1.09,1.04,1.12$ and 1.06, respectively. At $100 \mathrm{~m}$ depth, it was done only once during P3 and ID was 1.05. We therefore considered isotopic dilution to be insignificant for all our data sets and used the conversion factor after Kirchman (1993) of 1.55 ng C per pmol leucine incorporated. Radioactivity was measured using a Packard 1600 TR counter calibrated for tritium quenching directly on board the ship. Diel periodicity of BP and BP grazing were not considered in the present study; all incubations (those for BP and those for bacterial grazing) were made with the same water sample taken at noon.

\section{RESULTS}

\section{Ciliate, HNF and bacterial standing stocks}

The bacterial abundance varied by an order of magnitude, from $10^{5}$ to $10^{6}$ cells $\mathrm{ml}^{-1}$, in the 0 to $100 \mathrm{~m}$ layer in winter (P1) and spring (P2). Maximal values $(2.2 \times$ $10^{6}$ cells $\mathrm{ml}^{-1}$ ) occurred at the surface $(5 \mathrm{~m})$ of the southern anticyclonic eddy (A2, S1) in spring. In autumn (P3), abundances were always of the order of $10^{5}$ cells $\mathrm{ml}^{-1}$. Flow cytometry distinguished 2 bacterial subpopulations from their low (LNA) and high (HNA) nucleic acid contents. LNA bacteria represented $58 \pm 13,72 \pm 6$ and $55 \pm$ $14 \%$ (means \pm SD reported throughout) of total heterotrophic bacteria abundance during P1, P2 and P3, respectively. HNF densities ranged from 20 to $\sim 3800$ cells $\mathrm{ml}^{-1}$ during the 3 POMME cruises. Maxima were found at subsurface (20 to $30 \mathrm{~m})$ at the saddle point (S3) and the eddy A1 (S4) in spring. Mean HNF abundance over the study area was similar in winter and autumn $(960 \pm 60$ and $970 \pm 180$ cells $\mathrm{ml}^{-1}$, respectively). In spring, the mean value increased and presented higher variability (1900 \pm 700 cells $\mathrm{ml}^{-1}$ ). Ciliate abundance in the 0 to $100 \mathrm{~m}$ layer ranged from 12 to 1900 cells $\mathrm{l}^{-1}$ during the 3 cruises. High tintinnid abundance (1260 cells $\left.\mathrm{l}^{-1}\right)$ was recorded throughout the water column of the eddy A1 (S4) in spring. High tintinnid densities were also found in the eddy $\mathrm{C} 4$ in winter ( 900 cells $\left.\mathrm{l}^{-1}\right)$ and spring (450 cells $\left.\mathrm{l}^{-1}\right)$ and at the saddle point (200 cells $\left.\mathrm{l}^{-1}\right)$ in spring. Overall, mean ciliate abundance in the POMME area averaged $560 \pm 260,740 \pm 400$ and $160 \pm 40$ cells $^{-1}$ during P1, P2 and $\mathrm{P} 3$, respectively. The naked ciliate assemblage was dominated by aloricate species of the orders Oligotrichida and Choreotrichida: Strombidium spp., Laboea strobila, Tontonia spp. The taxonomic composition of loricate species (order Choreotrichida, suborder Tintinnna) was dominated by Dictyosysta spp. and Codonellopsis sp. in winter (P1) and Tintinnus sp. in spring (P2). In autumn (P3) we found the largest number of loricate species $(>17)$, but the lowest number of individuals. However, no particular species dominated the tintinnid assemblage. Biovolumes of different taxa

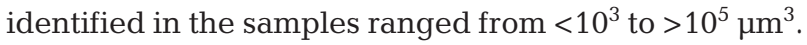

During the POMME cruises, bacteria, HNF and ciliate biomasses ranged from 2 to $33,<1$ to 12 and $<1$ to $9 \mu \mathrm{g} \mathrm{C}^{-1}$, respectively $(0$ to $100 \mathrm{~m}$ ). For all heterotrophs, maxima occurred in spring (P2). The total microbial heterotrophic biomass integrated over the upper $100 \mathrm{~m}$ averaged $1643 \pm 366 \mathrm{mg} \mathrm{C} \mathrm{m}^{-2}$ in winter (P1, Fig. 2A). An important increase of mean biomass was recorded in spring $\left(\mathrm{P} 2,2562 \pm 930 \mathrm{mg} \mathrm{C} \mathrm{m}^{-2}\right)$, which was mainly associated with the northern anticyclonic eddy A1 (S4) where biomass increased by a factor of 2.8 between P1 and P2 (Fig. 2A). Autumn was characterized by the lowest biomass, representing $951 \pm 337 \mathrm{mg} \mathrm{C} \mathrm{m}^{-2}$.

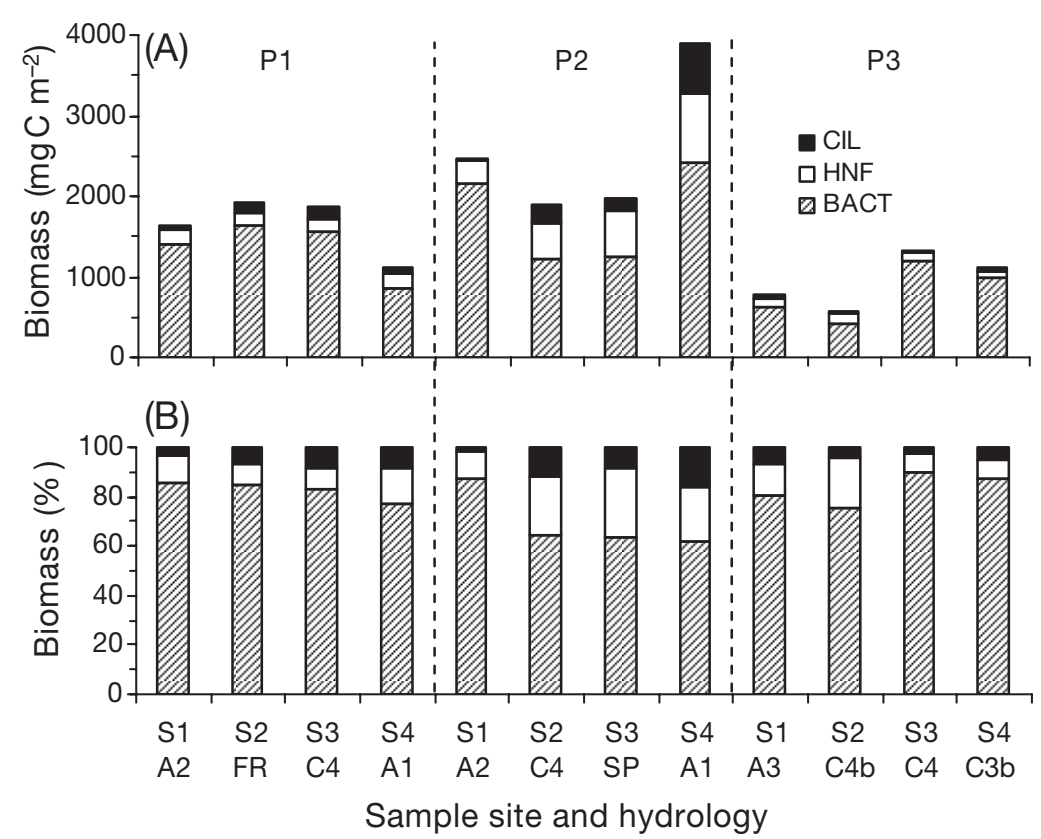

Fig. 2. Contribution of ciliates (CIL), heterotrophic nanoflagellates (HNF) and bacteria (BACT) to total heterotrophic biomass as (A) $\mathrm{mg} \mathrm{C} \mathrm{m}^{-2}$ and (B) percent at different sampling sites (S1 to S4) and hydrological structures in winter (P1), spring (P2) and autumn (P3). Data are integrated over the upper $100 \mathrm{~m}$. See Table 1 for abbreviations 

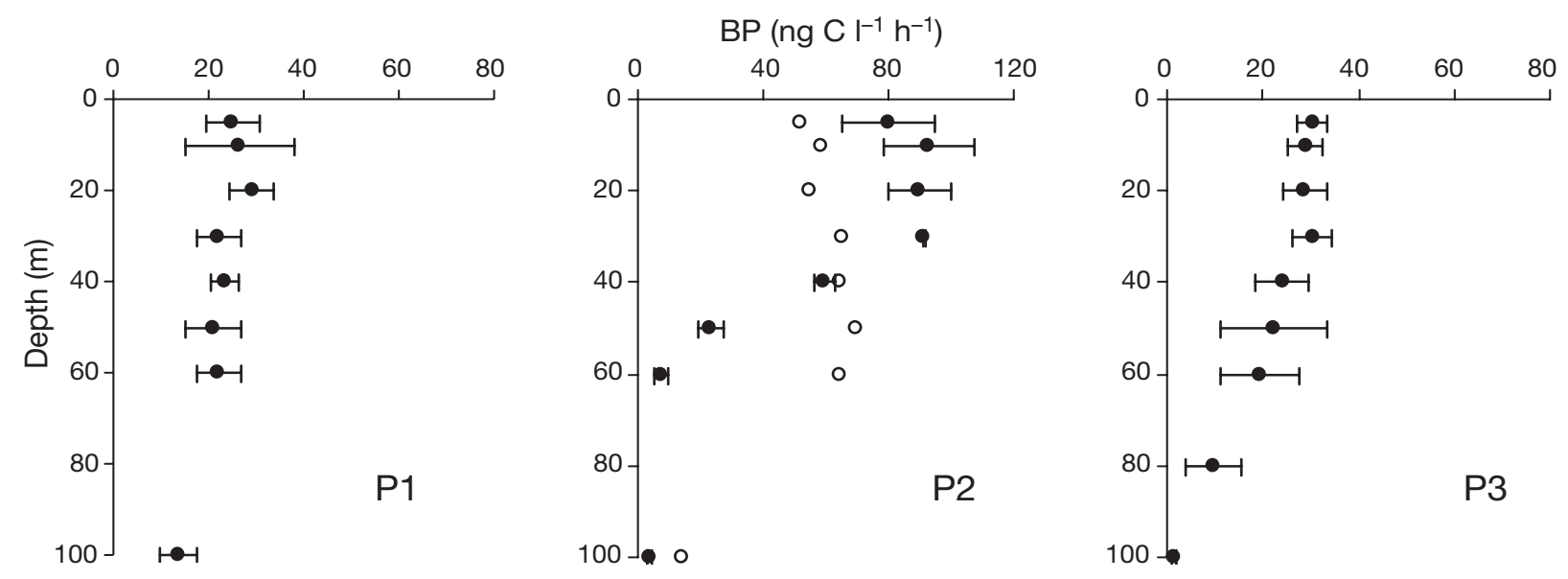

Fig. 3. Mean $\pm \mathrm{SD}$ vertical profiles of bacterial production $(\mathrm{BP}, \bullet)$ in winter $(\mathrm{P} 1)$, spring $(\mathrm{P} 2)$ and autumn (P3). In spring the vertical profile of BP at the anticyclonic eddy A1 (Site S4) is designated separately (O)

Bacteria were always the most important component of the heterotrophic assemblage, representing more than $62 \%$ of total heterotrophic biomass integrated over the upper $100 \mathrm{~m}$ (Fig. 2B). HNF constituted $11 \pm$ $5 \%$ of the total heterotrophic biomass in winter and autumn, and $21 \pm 7 \%$ in spring. The HNF biomass always exceeded that of ciliates (Fig. 2A,B). The contribution of ciliates to the total heterotrophic biomass was always less than 9\%, except at the eddies C4 (S2) and A1 (S4) in spring, where it reached 12 and $16 \%$, respectively (Fig. 2B). The ciliate community was dominated by naked oligotrich taxa (hereafter referred to as oligotrichs) except at the northern anticyclonic eddy A1 (S4) in spring where loricate species, mainly of the genus Tintinnus, represented $>70 \%$ of the integrated ciliate abundance and biomass.

\section{HNF and ciliate growth rates and production}

HNF growth rates varied from 0.2 to $0.7 \mathrm{~d}^{-1}$. Negative growth rate values for HNF were obtained in 5 of 20 experiments conducted during the 3 cruises. These values were not taken into account any further. Oligotrich and tintinnid growth rates ranged from 0.2 to 1.4 and 0.2 to $1.0 \mathrm{~d}^{-1}$, respectively, during P1 and P2 cruises; while most of the P3 cruise experiments gave negative results and could not be used any further. Based on growth rates, ciliate production (oligotrich and tintinnid) in winter and spring ranged from 30 to $210 \mathrm{mg} \mathrm{C} \mathrm{m}^{-2} \mathrm{~d}^{-1}$ (0 to $100 \mathrm{~m})$. Tintinnid production was lower than $10 \mathrm{mg} \mathrm{C} \mathrm{m}^{-2} \mathrm{~d}^{-1}$ except at the cyclonic eddy $\mathrm{C} 4$ (S2, $24 \mathrm{mg} \mathrm{C} \mathrm{m}^{-2} \mathrm{~d}^{-1}$ ), the saddle point (S3, $38 \mathrm{mg} \mathrm{C} \mathrm{m}^{-2}$ $\mathrm{d}^{-1}$ ) and the anticyclonic eddy A1 (S4, $141 \mathrm{mg} \mathrm{C} \mathrm{m}^{-2}$ $\mathrm{d}^{-1}$ ) in spring. This latter eddy was the only one where tintinnid production was greater (2.5-fold) than that of the oligotrichs. HNF production ranged from 24 to $372 \mathrm{mg} \mathrm{C} \mathrm{m} \mathrm{m}^{-2} \mathrm{~d}^{-1}$ and was always higher than that of ciliates.

\section{Bacterial production}

In winter (P1), BP was low $\left(23 \pm 7 \mathrm{ng} \mathrm{C} \mathrm{l}^{-1} \mathrm{~h}^{-1}\right)$ and was distributed evenly over the upper $60 \mathrm{~m}$ (Fig. 3). In spring (P2), vertical profiles of BP followed the northward thermal stratification of the surface layer. In particular, BP was higher in the upper $30 \mathrm{~m}$ of the southern anticyclonic eddy A2 (S1), the cyclonic eddy C4

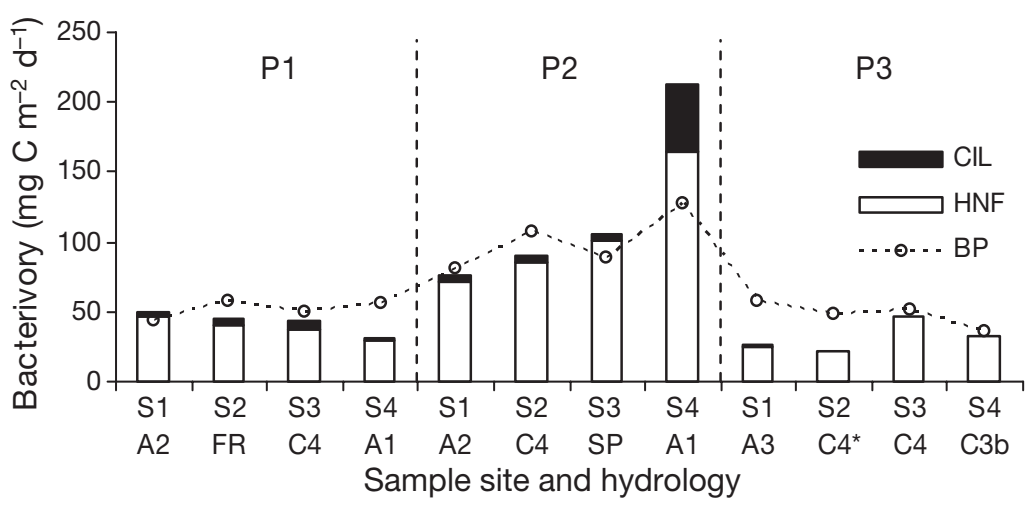

Fig. 4. Ciliate (CIL) and heterotrophic nanoflagellate (HNF) bacterivory plotted with bacterial production (BP) at different sampling sites and hydrological structures. Data are integrated over the upper 100 m. During P1 and P2 integrated BP was calculated with only 2 points between 60 and $100 \mathrm{~m}$ instead of 3 (cf. Fig. 3). See Table 1 for abbreviations 


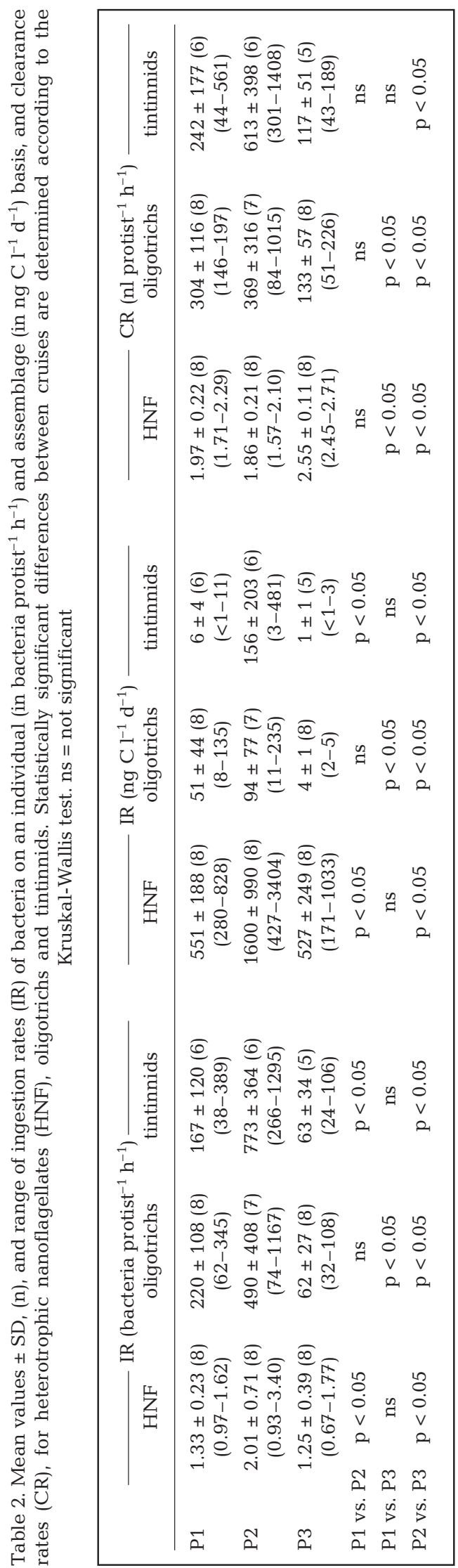

(S2) and the saddle point (S3), but was distributed more homogenously in the northern anticyclonic eddy A1 (S4, Fig. 3). During P2, BP reached its maximum (112 $\mathrm{ng} \mathrm{C} \mathrm{l}^{-1} \mathrm{~h}^{-1}, \mathrm{~A} 2$ ) and averaged $52 \pm 34 \mathrm{ng} \mathrm{Cl}^{-1} \mathrm{~h}^{-1}$ over the 4 sampling sites. In autumn (P3), BP dropped to winter levels $\left(22 \pm 11 \mathrm{ng} \mathrm{C} \mathrm{l}^{-1} \mathrm{~h}^{-1}\right)$. Vertical profiles showed higher bacterial carbon production at the surface between 0 and $30 \mathrm{~m}$ (Fig. 3).

BP integrated over the upper $100 \mathrm{~m}$ varied slightly during $\mathrm{P} 1$ and $\mathrm{P} 3$, ranging from 43 to 58 and 36 to $57 \mathrm{mg} \mathrm{C} \mathrm{m}^{-2} \mathrm{~d}^{-1}$, respectively (Fig. 4). Integrated BP increased by over $85 \%$ from winter (P1) to spring (P2) in each of the 3 eddies that were sampled during both seasons (A1, C4, A2). During P2, the highest depth-integrated BP was recorded at the northern eddy A1 (S4, $127 \mathrm{mg} \mathrm{C} \mathrm{m}^{-2} \mathrm{~d}^{-1}$ ) whereas the lowest value was recorded at the southern eddy A2 (S1, $\left.81 \mathrm{mg} \mathrm{C} \mathrm{m}^{-2} \mathrm{~d}^{-1}\right)$.

\section{Ciliate and nanoflagellate bacterivory}

HNF ingestion rates of bacteria varied between 0.67 and 3.40 bacteria protist ${ }^{-1} \mathrm{~h}^{-1}$ during the 3 POMME cruises (Table 2). Ingestion rates for oligotrichs ranged from 32 to 1167 bacteria protist ${ }^{-1} \mathrm{~h}^{-1}$ and for tintinnids from 24 to 1295 bacteria protist ${ }^{-1} \mathrm{~h}^{-1}$. The highest values were always measured in spring (P2). For HNF and oligotrichs, maxima were associated with the southern anticyclonic eddy A2 (S1) where the highest bacterial abundance was recorded $\left(2.2 \times 10^{6}\right.$ bacteria $\left.\mathrm{ml}^{-1}\right)$. Maximum tintinnid ingestion rates on bacteria occurred at the eddy A1 (S4) during the Tintinnus sp. bloom.

Total bacterivory and BP integrated over the upper $100 \mathrm{~m}$ are presented in Fig. 4. Integrated bacterivory showed a weak spatial variability in winter (P1) and ranged from 43 to $49 \mathrm{mg} \mathrm{C} \mathrm{m}^{-2} \mathrm{~d}^{-1}$ except in the north (A1, S4) where it was slightly lower $\left(31 \mathrm{mg} \mathrm{C} \mathrm{m}^{-2} \mathrm{~d}^{-1}\right)$. Bacterivory increased in spring by factors of 1.6, 2.8 and 6.8 in $\mathrm{A} 2, \mathrm{C} 4$ and $\mathrm{A} 1$, respectively (P2, Fig. 4). The lowest integrated value of bacterial consumption was recorded in $\mathrm{A} 2$ in the south $\left(76 \mathrm{mg} \mathrm{C} \mathrm{m}^{-2} \mathrm{~d}^{-1}\right)$, whereas the highest was related to the eddy A1 in the north (212 $\mathrm{mg} \mathrm{C} \mathrm{m}^{-2} \mathrm{~d}^{-1}$ ). In autumn (P3), integrated bacterivory was lower than in winter, except at the cyclone $\mathrm{C} 4$ where it remained similar $\left(46 \mathrm{mg} \mathrm{C} \mathrm{m}^{-2} \mathrm{~d}^{-1}\right)$. Generally, during the POMME cruises bacterivory balanced with BP (Fig. 4). Bacterivory accounted for a lower amount of integrated BP at the eddy A1 (57\%) in winter and the eddies A31 (45\%) and C4 (boundaries, $46 \%$ ) in autumn (Fig. 4). Bacterivory exceeded BP in 3 sampling sites; the eddy A2 in winter $(115 \%)$, the saddle point $(119 \%)$ and the eddy A1 (167\%) in spring (Fig. 4). Ciliates always accounted for a minor part of total bacterivory $(\leq 10 \%$ of integrated $\mathrm{BP})$, except during the Tintinnus sp. spring bloom at the eddy A1 (37\%). 


\section{DISCUSSION}

Heterotrophic microbial abundance, biomass and protistan grazing varied temporally, presenting their highest values during the phytoplankton bloom during spring (P2) and following the northward propagation of the bloom. Moreover, data from sediment traps have also shown that the biological functioning of the studied structures was largely controlled by the south-north gradient of production in relation with the depth of the mixed layer and the seasonality (Goutx et al. 2005).

Bacterial densities recorded during the POMME cruises were slightly higher than in previous seasonal studies conducted in the northeast Atlantic Ocean (e.g. Buck et al. 1996, Zubkov et al. 2000b, Bode et al. 2001, see also the review article of Marañón et al. 2007). In particular, bacterial abundance reached $2.2 \times 10^{6}$ cells $\mathrm{ml}^{-1}$ in spring (P2) and $1.1 \times 10^{6}$ cells ml $\mathrm{m}^{-1}$ in autumn (P3), whereas maximal values reported in previous studies were $1.3 \times 10^{6}$ (Zubkov et al. 2000b) and $5.9 \times$ $10^{5}$ cells ml ${ }^{-1}$ (Bode et al. 2001), respectively. Summer values reported in earlier studies were intermediate compared with our spring and autumn data and reached $1.5 \times 10^{6}$ cells ml $^{-1}$ (Buck et al. 1996). Maximal values similar to these $\left(2.2 \times 10^{6}\right.$ bacteria $\mathrm{ml}^{-1}$, A2 during P2) have been found in the oligotrophic Sargasso Sea (Fuhrman et al. 1989). Integrated bacterial biomass increased 1.5- and 3-fold in the 2 anticyclonic eddies (A2 and A1, respectively) between winter and spring. Bacterial abundance and biomass in A2 was probably enhanced by the increased availability of organic matter that occurs during the declining phase of a phytoplankton bloom. Indeed, it is likely that at the southern eddy A2 sampling was conducted during this late stage, as the spring bloom in the POMME area was initiated in the southwest between February and March, and migrated to the north afterwards. High bacterial biomass and production in A1, where the Pseudo-nitzschia sp. bloom was recorded, suggests that bacteria were positively responding to phytoplankton derived DOM, creating new biomass. Despite the high bacterial abundance, bacterial production in the POMME area was lower than that reported in earlier studies $\left(\geq 100 \mathrm{mgC} \mathrm{m} \mathrm{m}^{-1}\right.$, e.g. Lochte \& Pfannkuche 1987, Ducklow et al. 1993) except at the anticyclonic eddy A1 (S4) where it reached $127 \mathrm{mg} \mathrm{C}$ $\mathrm{m}^{-2} \mathrm{~d}^{-1}$. Low BP during POMME was probably related to the high proportion of inactive (low nucleic acid) bacteria (62 $\pm 13 \%$, all data included) as was previously suggested by Vaqué et al. (2001). Furthermore, other sources of discrepancies may arise from the different techniques applied in the previous studies, leucine (this study) and thymidine incorporation (Ducklow et al. 1993), and the frequency of dividing cells (Lochte \& Pfannkuche 1987).
HNF and ciliate abundance and biomass as well as the taxonomic composition of the ciliate assemblage were comparable with those previously reported for the northeast Atlantic Ocean (see Karayanni et al. 2005 and references therein for details). HNF biomass integrated over the upper $100 \mathrm{~m}$ was lower than $200 \mathrm{mg} \mathrm{C} \mathrm{m}^{-2}$ in winter and autumn. In spring, HNF biomass ranged from 270 to $850 \mathrm{mg} \mathrm{C} \mathrm{m}^{-2}$. Spring values compared well with those found in a North Atlantic Ocean upwelling event by Fileman \& Burkill (2001), while winter values are close to those reported for the associated oligotrophic offshore waters. Tintinnid abundance and biomass recorded in the A1 (S4) in spring are the highest yet reported for the northeast Atlantic Ocean. High ciliate stock, associated with increased tintinnid biomass, has also been reported for the subarctic Pacific Ocean (Sime-Ngando et al. 1992) and the Southern Ocean (Christaki et al. 2008). Also, there is evidence that tintinnids characterized by short generation times proliferate in high trophic conditions (Lam-Hoai et al. 2006). Data on nanophytoplankton abundance and biomass in A1 are lacking. However, the Pseudo-nitzschia sp. bloom indicates that this site can support high phytoplankton biomass, which probably triggered the opportunistic feeding behavior of tintinnids.

Among the various methods applied to measure protistan grazing on bacteria (e.g. dilution experiments, radioactively labeled bacteria, disappearance of minicells), uptake of fluorescently labeled preys (FLP) is the most commonly used. The use of FLBs as bacterial surrogates has known limitations, such as disturbance of the sample and underestimation of bacterial losses by selection of prey. This technique has been widely discussed in previous studies (e.g. Vázquez-Domínguez et al. 1999, Vaqué et al. 2002). Aside from these methodological limitations, we believe our results validate a winter-spring-autumn pattern with a higher grazing rate in spring. Furthermore, the ingestion technique (direct counts of FLB inside digestive vacuoles) identifies the grazers. Finally, the size of FLB compared with natural bacterioplankton can be one of the limitations of this method. Data from different oceanic provinces have shown an average bacterial size of 0.049 to $0.07 \mu^{3}$ for Antarctic waters (Vaqué et al. 2002) and 0.06 to $0.08 \mu^{3}$ for the Mediterranean Sea (Vaqué et al. 2001). According to VázquezDomínguez et al. (2005) and Zubkov et al. (2000a) average biovolume of bacterioplankton in the northeast Atlantic Ocean ranged between 0.036 and $0.051 \mathrm{\mu m}^{3}$, which is very close to that of Brevundimonas diminuta strains $(0.064 \mu \mathrm{m})$ used in this study. Comparison with other marine systems showed that HNF ingestion rates ( 0.67 to 3.40 bacteria protist ${ }^{-1} \mathrm{~h}^{-1}$ ) fell within the low range of values previously reported $\left(\sim 1\right.$ to $10^{2}$ bacteria protist ${ }^{-1} \mathrm{~h}^{-1}$, Table 3$)$. Low HNF 
Table 3. Parameters of bacterial consumption by heterotrophic nanoflagellates (HNF) and ciliates in different aquatic ecosystems; $\mathrm{IR}=$ ingestion rates in bacteria protist ${ }^{-1} \mathrm{~h}^{-1}$ and $\mathrm{CR}=$ clearance rate in nl protist ${ }^{-1} \mathrm{~h}^{-1}$. VC $=$ vacuole content, $\mathrm{D}=$ prey disappearance, $\mathrm{BACT}=$ bacteria, FLB = fluorescently labeled bacteria, FLM = fluorescently labeled minicells

\begin{tabular}{|lcccl}
\hline Study site & IR & CR & Method & Source \\
\hline HNF & & & & \\
Boston Harbor & - & $5.3 \pm 1.8$ & VC (FLB) & Epstein \& Shiaris (1992) \\
Estuary & - & $0.32-5.01$ & VC (FLB) & Gonzalez et al. (1990) \\
Hudson Estuary & $1-19$ & - & VC (FLM) & Vaqué et al. (1992) \\
Mediterranean (5-34 ${ }^{\circ}$ E) & $0.9-4.3$ & $2.15-12.4$ & VC/D (FLB) & Christaki et al. (2001) \\
E Mediterranean & - & $2.6 \pm 0.78$ & VC (FLM) & Christaki et al. (1999) \\
NW Mediterranean & $5-6$ & $5.8-7.7$ & VC (FLM) & Van Wambeke et al. (1995) \\
NW Mediterranean & $1-32$ & - & D (FLB, BACT, FLM) & Vázquez-Domínguez et al. (1999) \\
Takapoto Atoll & $107.6 \pm 44.5$ & $57 \pm 20$ & VC (FLB) & Sakka et al. (2000) \\
Vineyard Sound & $10.5-26$ & $4.6-11$ & Metabolic inhibitors & Caron et al. (1991) \\
NE Atlantic (P1) & $0.97-1.62$ & $1.51-2.29$ & VC (FLB) & Present study \\
NE Atlantic (P2) & $0.93-3.40$ & $1.57-2.10$ & VC (FLB) & Present study \\
NE Atlantic (P3) & $0.67-1.77$ & $2.45-2.71$ & VC (FLB) & Present study \\
Ciliates & & & & \\
Boston Harbor & $\leq 225$ & $90 \pm 24$ & VC (FLB) & Epstein \& Shiaris (1992) \\
Estuary & - & $54-406$ & VC (FLB) & Gonzalez et al. (1990) \\
Hudson Estuary & $118-506$ & - & D (FLM) & Vaqué et al. (1992) \\
Bay of Villefranche, & $6-630$ & $14-308$ & VC (FLB) & Sherr et al. (1989) \\
NW Mediterranean & & & & \\
Rimov Reservoir & $80-2000$ & - & VC (FLB) & Šimek et al. (1995) \\
Takapoto Atoll & $27.7 \pm 8.3$ & $15 \pm 4$ & VC (FLB) & Sakka et al. (2000) \\
NE Atlantic (P1) & $62-389$ & $40-560$ & VC (FLB) & Present study \\
NE Atlantic (P2) & $74-1295$ & $80-1410$ & VC (FLB) & Present study \\
NE Atlantic (P3) & $24-108$ & $40-230$ & VC (FLB) & Present study \\
\hline
\end{tabular}

ingestion rates can be attributed to relatively low bacterial concentrations. Indeed, during the POMME cruises, bacterial abundance was less or equal to the lower limit of the half-saturation constants calculated by Fenchel (1982) for different HNF species $\left(1.3 \times 10^{6}\right.$ to $3.8 \times 10^{9}$ bacteria $\mathrm{ml}^{-1}$ ), indicating a food limitation on ingestion rates. In addition, Vaqué et al. (2002) showed that HNF bacterivory increased with prey concentration, which supports our results.

Ciliate ingestion rates (32 to 600 bacteria protist ${ }^{-1}$ $\mathrm{h}^{-1}$ ) overlap with values found in earlier studies (Table 3). Considerably higher rates, comparable with those recorded in a eutrophic freshwater ecosystem (Šimek et al. 1995), were measured in eddies A2 and A1 in spring $\left(>10^{3}\right.$ bacteria protist $\left.{ }^{-1} \mathrm{~h}^{-1}\right)$. Several researchers have reported that a minimal bacterial concentration exists, above which ciliates may present significant grazing activity on bacteria (e.g. Fenchel 1980). While the exact level of this threshold is under question, our findings show that predation on bacteria increased when prey abundance was of the order of $10^{6} \mathrm{ml}^{-1}$ (e.g. anticyclonic eddies A2 and A1).

Data on clearance rates of ciliates on bacteria in situ are scarce. The lower rates recorded here (mostly $<500 \mathrm{nl}$ protist ${ }^{-1} \mathrm{~h}^{-1}$ ) fall within the range of values previously reported for different aquatic environments (Table 3). However, the highest value measured during the tintinnid bloom (1410 $\mathrm{nl}$ protist ${ }^{-1} \mathrm{~h}^{-1}$ in $\left.\mathrm{A} 1\right)$ is 3.5 - fold higher than those reported by Gonzalez et al. (1990) in an estuary (Table 3). Fenchel (1980) measured ciliate clearance on bacteria in culture conditions of the order of $10^{4}$ to $4 \times 10^{5}$ body volumes $\mathrm{h}^{-1}$. During our

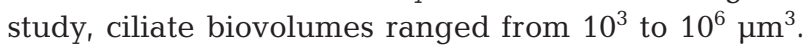
Considering a clearance rate of $10^{4}$ of their body volume per hour, clearance rates between 10 and $10000 \mathrm{nl}$ protist $^{-1} \mathrm{~h}^{-1}$ were obtained. The latter value (10000 nl protist $^{-1} \mathrm{~h}^{-1}$ ) is also considered as the maximum clearance rate of ciliates in situ (Dolan \& McKeon 2005).

Although bacterial ingestion rates were much lower for HNF than for ciliates, HNF accounted for $>78 \%$ of the total bacterial carbon consumed (in $\mathrm{mg} \mathrm{C} \mathrm{m}^{-2} \mathrm{~d}^{-1}$ ) in the upper $100 \mathrm{~m}$. Overall, total protist bacterivory balanced or even exceeded BP in most of the sampling sites visited during the POMME cruises (Fig. 4). Existing field data have shown that bacterivory plays an important role in the fate of BP in different oligotrophic systems, such as the Sargasso Sea (Caron et al. 1999), the eastern Mediterranean (Christaki et al. 1999) or the stratified tropical/subtropical and temperate waters of the Atlantic Ocean (Zubkov et al. 2000a, VázquezDomínguez et al. 2005), accounting for 40 to $100 \%$ of it. The fraction of BP lost through bacterivory exceeded $100 \%$ in spring at the saddle point (SP, S3) and the northern anticyclonic eddy A1 (S4), where the highest integrated abundance and biomass of HNF and/or ciliates were recorded (Figs. $2 \& 4$ ). Both SP and A1 were 

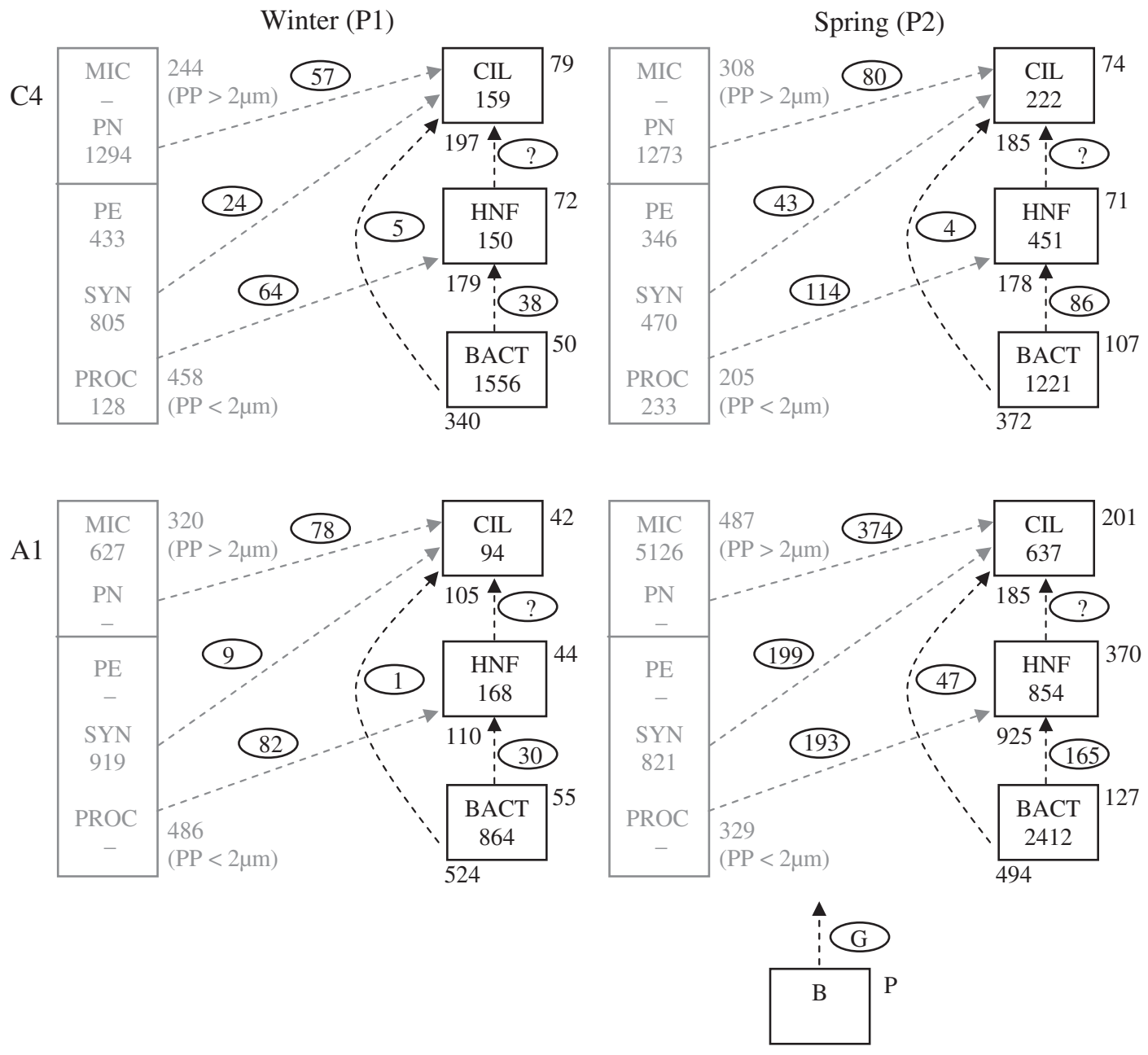

$\mathrm{CD}$

Fig. 5. Carbon flux (0 to $100 \mathrm{~m}$ ) within the microbial food web in the cyclonic eddy (C4) and the anticyclonic eddy (A1) in winter (P1) and spring (P2). The left part of the figure (in grey) represents the fluxes from primary producers to protists described in Karayanni et al. (2005). MIC = microphytoplankton, $\mathrm{PN}=$ photosynthetic nanoflagellates, $\mathrm{PE}=$ photosynthetic pikoeucaryotes, $\mathrm{SYN}=$ Synechococcus, $\mathrm{PROC}=$ Prochlorococcus. Primary production $\left(\mathrm{PP}, \mathrm{mg} \mathrm{C} \mathrm{m}^{-2} \mathrm{~d}^{-1}\right)$ is divided into 2 parts: cells $>2 \mu \mathrm{m}$ (upper part) and cells $<2 \mu \mathrm{m}$ (lower part). $-=$ no data. The right part of the figure summarises the data presented in this paper. $\mathrm{BACT}=$ bacteria, $\mathrm{HNF}=$ heterotrophic nanoflagellates, $\mathrm{CIL}=$ ciliates, $\mathrm{CD}=$ carbon demand $\mathrm{B}=$ biomass, $\mathrm{P}=$ production, $\mathrm{G}=$ grazing . Stocks (biomass, $B$ ) are in $\mathrm{mg} \mathrm{C} \mathrm{m}{ }^{-2}$ and fluxes $\left(\mathrm{G}, \mathrm{P}\right.$ and $\mathrm{CD}$ ) in $\mathrm{mg} \mathrm{C} \mathrm{m}^{-2} \mathrm{~d}^{-1}$

located in the more productive north domain of the POMME area, which seems to support higher protist abundance and biomass that, in turn, exert higher grazing pressure on BP. The role of viruses on the fate of BP was not addressed in this or in previous studies conducted in the area. The only available data concern the mesotrophic western Atlantic Ocean where Hewson \& Fuhrman (2007) estimated that bacterial production lost to virus lysis ranged between $<1$ and $27 \%$. Although further research on the role of viruses is needed, these results reinforce our findings that grazing, rather than virus infection, exerts a strong control on BP, as also suggested by Vázquez-Domínguez et al. (2005) for the oligotrophic central Atlantic Ocean.
Information on growth rates of natural assemblages of protists is limited mainly because of the absence of a direct method of measurement and the inconvenience of the indirect methods involved (i.e. time consuming counting, possible cell loss during fractionation and bottle effect; Gifford \& Caron 2000). Thus, negative values obtained during P3 for ciliates can be explained by very low initial ciliate abundance (of the order of 1 to $2.2 \times 10^{2}$ ciliates $1^{-1}$ ), combined with probable loss of cells during fractionation and the overall oligotrophic conditions (low number of preys) encountered during this cruise. HNF growth rates reported here ( 0.2 to $0.7 \mathrm{~d}^{-1}$ ) are in the range obtained during the North Atlantic Bloom Experiment (NABE) by fraction- 
ation and dilution techniques $\left(0.2\right.$ to $1.0 \mathrm{~d}^{-1}$, Verity et al. 1993), but low compared with a high productivity region such as the Oregon upwelling systems (>0.7 $\mathrm{d}^{-1}$, Neuer \& Cowles 1994). Ciliate growth rates reached $1.4 \mathrm{~d}^{-1}$ in the saddle point where the highest primary production was measured (Karayanni et al. 2005). Similar maximal values were recorded during NABE (1.2 d $\mathrm{d}^{-1}$, Verity et al. 1993).

Carbon fluxes within the microbial food web are summarized in Fig. 5 at the 4 selected characteristic situations (A1 and C4 in winter and spring) where a low ( $<4 \%, \mathrm{~A} 1$ in winter and $\mathrm{C} 4$ in spring), an intermediate $(10 \%, \mathrm{C} 4$ in winter) and a high $(37 \%, \mathrm{~A} 1 \mathrm{in}$ spring) percentage of BP is consumed directly by ciliates. Bacterial production, as well as HNF and ciliate biomass, increased from winter to spring in both eddies, while that of heterotrophic bacteria increased in $\mathrm{A} 1$ but decreased $22 \%$ in $\mathrm{C} 4$.

In the northern eddy A1, loricate species (mainly Tintinnus sp.) dominated the ciliate assemblage, accounting for more than $70 \%$ of ciliate abundance and biomass. Grazing experiments indicated that these species ingested small heterotrophic bacteria and were the main bacterivores within the ciliate assemblage, consuming $\sim 30 \%$ of BP.

Protist carbon demand was calculated assuming a growth efficiency (GE) of $40 \%$ (Ducklow 1983, Fenchel 1986). Bacterial ingestion accounted for $23 \%$ (C4, winter), $35 \%$ (A1, winter), $48 \%$ (C4, spring) and 18\% (A1, spring) of the HNF carbon demand and $<10 \%$ of that of ciliates (Fig. 5). In a recent study by Karayanni et al. (2005), HNF and ciliate ingestion rates on pico- and nanophytoplankton were measured in the POMME project area. Considering both herbivory and bacterivory, total ingested carbon (Synechococcus, Prochlorococcus and heterotrophic bacteria) met HNF carbon demand in both the anticyclonic eddy A1 in winter (P1) and the cyclonic eddy $\mathrm{C} 4$ in spring (P2, Fig. 5). For ciliates, total ingested carbon (Synechococcus, photosynthetic eukaryotes $<4 \mu \mathrm{m}$ and heterotrophic bacteria) exceeded carbon demand in the anticyclonic eddy A1 in spring (Fig. 5). However, in some cases (i.e. cyclonic eddy $\mathrm{C} 4$ in winter), protist carbon demand was somewhat higher than total ingested prokaryotic and eukaryotic carbon measured in grazing experiments. It is most likely that in these cases other carbon sources (e.g. larger phytoplankton or DOM) contributed to their diet.

\section{CONCLUSIONS}

Our data showed that HNF can remove a large percentage of $\mathrm{BP}$ in the northeast Atlantic Ocean (83 \pm $27 \%$, average of all sampling sites and seasons). How- ever, since heterotrophic nanoplankton (HNF) is potential prey for ciliates, then up to $52 \%$ of BP (A1 in spring) could be transferred to ciliates via HNF (i.e. [0.4 growth efficiency $\times$ BP grazed by $\mathrm{HNF}] \div \mathrm{BP}$ ). Episodic blooms, such as that of tintinnids recorded in the northern anticyclonic eddy A1 in spring, may represent a food web shortcut within the microbial food web and considerably increase the amount of BP that is available to higher consumers (e.g. copepods). For example, we found that the percentage of BP that is available to copepods through direct ciliate bacterivory varies between 0.7 and $14.8 \%$ in the 3 sites, which represent low (A1 in winter), intermediate (C4 in winter) and high (A1 in spring) consumption on bacteria, respectively $(\mathrm{GE}=40 \%)$. This shows that the consumption of BP by ciliates may represent a considerable pathway through which bacterial biomass may reach higher consumers in the northeast Atlantic Ocean.

Overall, our data showed that ciliate ingestion rates overlap with values found in fresh, coastal or estuarine waters. However, due to their low abundance, ciliate bacterivory accounted for a low percentage of $\mathrm{BP}$, except during a tintinnid bloom when a large fraction of BP $(37 \%)$ was consumed by ciliates. Although our results showed that ingestion of bacteria by ciliates is possible in oceanic waters, further studies are needed to elucidate the extent (Is it a generality or a peculiarity?) of this phenomenon and its real ecological significance.

Acknowledgements. This work is a contribution to the POMME program. Financial support was provided by CNRSINSU, France. We thank Dr. D. Vaqué, ICM, Barcelona, Spain, for providing cultures of Brevundimonas diminuta and Dr. M. Holbraad and P. Magee for correcting the English of the manuscript. Thanks also to our many colleagues who participated in the collection of various data sets and the crews of the RVs 'Atalante' and 'Thalassa' for valuable assistance.

\section{LITERATURE CITED}

Bode A, Barquero S, Varela M, Braun JG, de Armas D (2001) Pelagic bacteria and phytoplankton in oceanic waters near the Canary Islands in summer. Mar Ecol Prog Ser 209:1-17

Børsheim KY, Bratbak G (1987) Cell volume to cell carbon conversion factors for a bacterivorous Monas sp. enriched from seawater. Mar Ecol Prog Ser 36:171-175

> Buck KR, Chavez FP, Campbell L (1996) Basin-wide distributions of living carbon components and the inverted trophic pyramid of the central gyre of the North Atlantic Ocean, summer 1993. Aquat Microb Ecol 10:283-298

> Caron DA, Lim EL, Miceli G, Waterbury JB, Valois FW (1991) Grazing and utilization of chroococcoid cyanobacteria and heterotrophic bacteria by protozoa in laboratory cultures and a coastal plankton community. Mar Ecol Prog Ser $76: 205-217$ 
Caron DA, Dam HG, Kremer P, Lessard EJ and others (1995) The contribution of microorganisms to particulate carbon and nitrogen in surface waters of the Sargasso Sea near Bermuda. Deep-Sea Res I 42:943-972

Caron DA, Peele ER, Lim EL, Dennett MR (1999) Picoplankton and their trophic coupling in surface waters of the Sargasso Sea of Bermuda. Limnol Oceanogr 44:259-272

Christaki U, Van Wambeke F, Dolan JR (1999) Nanoflagellates (mixotrophs, heterotrophs and autotrophs) in the oligotrophic eastern Mediterranean: standing stocks, bacterivory and relationships with bacterial production. Mar Ecol Prog Ser 181:297-307

Christaki U, Giannakourou A, Van Wambeke F, Grégori G (2001) Nanoflagellate predation on auto- and heterotrophic picoplankton in the oligotrophic Mediterranean Sea. J Plankton Res 23:1297-1310

Christaki U, Obernosterer I, Van Wambeke F, Veldhuis M, Garcia N, Catala P (2008) Microbial food web structure in a naturally iron fertilized area in the Southern Ocean (Kerguelen Plateau). Deep-Sea Res II, doi:10.101/j.dsr2.2007/ 12.009

Dolan JR, McKeon K (2005) The reliability of grazing rate estimates from dilution experiments: Have we over-estimated rates of organic carbon consumption by microzooplankton? Ocean Sci 1:1-7

Ducklow HW (1983) Production and fate of bacteria in the oceans. BioScience 33:494-501

Ducklow HW (1991) The passage of carbon through microbial foodwebs: results from flow network models. Mar Microb Food Webs 5:123-144

Ducklow HW, Kirchman DL, Quinby HI, Carlson CA, Dam HG (1993) Stocks and dynamics of bacterioplankton carbon during the spring bloom in the eastern North Atlantic Ocean. Deep-Sea Res II 40:245-263

Epstein SS, Shiaris MP (1992) Size-selective grazing of coastal bacterioplankton by natural assemblages of pigmented flagellates, colorless flagellates and ciliates. Microb Ecol 23:211-225

Fenchel T (1980) Suspension feeding in ciliated protozoa: feeding rates and their ecological significance. Microb Ecol 6:13-25

Fenchel T (1982) Ecology of heterotrophic microflagellates II. Bioenergetics and growth. Mar Ecol Prog Ser 8:225-231

Fenchel T (1986) The ecology of heterotrophic flagellates. Adv Microb Ecol 9:57-95

Fileman E, Burkill P (2001) The herbivorous impact of microzooplankton during two short-term Lagrangian experiments off the NW coast of Galicia in summer 1998. Prog Oceanogr 51:361-383

Frost BW (1972) Effects of size and concentration of food particles on the feeding behavior of the marine planktonic copepod Calanus pacificus. Limnol Oceanogr 17:805-817

Fuhrman JA, Sleeter TD, Carlson CA, Proctor LM (1989) Dominance of bacterial biomass in the Sargasso Sea and its ecological implications. Mar Ecol Prog Ser 57:207-217

Gifford DJ, Caron DA (2000) Sampling, preservation, enumeration and biomass of marine protozooplankton. In: Harris RP, Wiebe PH, Lenz J, Skjoldal HR, Huntley M (eds) ICES zooplankton methodology manual. Academic Press, MPG Books, Cornwall, p 193-221

Gonzalez JM, Sherr EB, Sherr BF (1990) Size-selective grazing on bacteria by natural assemblages of estuarine flagellates and ciliates. Appl Environ Microbiol 56:583-589

Goutx M, Guigue C, Leblond N, Desnues A, Dufour A, Aritio D, Guieu C (2005) Particle flux in the northeast Atlantic Ocean during the POMME experiment (2001): results from mass, carbon, nitrogen, and lipid biomarkers from the drifting sediment traps. J Geophys Res C, doi:10.1029/2004JC002749

Hewson I, Fuhrman JA (2007) Covariation of viral parameters with bacterial assemblage richness and diversity in the water column and sediments. Deep-Sea Res I 54:811-830

Hoppe HG, Gocke K, Koppe R, Begler C (2002) Bacterial growth and primary production along a north-south transect of the Atlantic Ocean. Nature 416:168-171

Karayanni H, Christaki U, Van Wambeke F, Dalby AP (2004) Evaluation of double formalin - Lugol's fixation in assessing number and biomass of ciliates. An example of estimations at mesoscale in NE Atlantic. J Microbiol Methods 56:349-358

Karayanni H, Christaki U, Van Wambeke F, Denis M, Moutin $\mathrm{T}$ (2005) Influence of ciliated protozoa and heterotrophic nanoflagellates on the fate of primary production in NE Atlantic Ocean. J Geophys Res C, doi:10.1029/ 2004JC002602

Kirchman DL (1993) Leucine incorporation as a measure of biomass production by heterotrophic bacteria. In: Kemp PF, Sherr BF, Sherr EB, Cole JJ (eds) Handbook of methods in aquatic microbial ecology. Lewis Publishers, Boca Raton, FL, p 509-512

Lam-Hoai T, Guiral D, Rougier C (2006) Seasonal change of community structure and size spectra of zooplankton in the Kaw River estuary (French Guiana). Estuar Coast Shelf Sci 68:47-61

Lévy M, Gavart M, Mémery L, Caniaux G, Paci A (2005) A four-dimensional mesoscale map of the spring bloom in the northeast Atlantic (POMME experiment): results of a prognostic model. J Geophys Res C, doi:10.1029/ 2004JC002588

Lochte K, Pfannkuche O (1987) Cyclonic cold-core eddy in the eastern North Atlantic. II. Nutrients, phytoplankton and bacterioplankton. Mar Ecol Prog Ser 39:153-164

Maixandeau A, Lefèvre D, Karayanni H, Christaki U and others (2005) Microbial community production, respiration and structure of the microbial food web of an ecosystem in the Northeastern Atlantic Ocean. J Geophys Res C, doi:10.1029/2004JC002694

Marañón E, Pérez V, Fernández E, Anadón R and others (2007) Planktonic carbon budget in the eastern subtropical North Atlantic. Aquat Microb Ecol 48:261-275

Neuer S, Cowles TJ (1994) Protist herbivory in the Oregon upwelling system. Mar Ecol Prog Ser 113:147-162

Putt M, Stoecker DK (1989) An experimentally determined carbon: volume ratio for marine 'oligotrichous' ciliates from estuarine and coastal waters. Limnol Oceanogr 34:1097-1103

Rivkin RB, Putland JN, Anderson MR, Deibel D (1999) Microzooplankton bacterivory and herbivory in the NE subarctic Pacific. Deep-Sea Res II 46:2579-2618

Sakka A, Legendre L, Gosselin M, Delesalle B (2000) Structure of the oligotrophic planktonic food web under low grazing of heterotrophic bacteria: Takapoto Atoll, French Polynesia. Mar Ecol Prog Ser 197:1-17

Sherr EB, Rassoulzadegan F, Sherr BF (1989) Bacterivory by pelagic choreotrichous ciliates in coastal waters of the NW Mediterranean Sea. Mar Ecol Prog Ser 55:235-240

Sime-Ngando T, Juniper K, Vézina A (1992) Ciliated protozoan communities over Cobb Seamount: increase in biomass and spatial patchiness. Mar Ecol Prog Ser 89:37-51

Šimek K, Bobková J, Macek M, Nedoma J, Psenner R (1995) Ciliate grazing on picoplankton in a eutrophic reservoir during the summer phytoplankton maximum: a study at the species community level. Limnol Oceanogr 40: $1077-1090$ 
Thyssen M, Lefèvre D, Caniaux G, Ras J, Fernández CI, Denis M (2005) Spatial distribution of heterotrophic bacteria in the northeast Atlantic (POMME study area) during spring 2001. J Geophys Res C, doi:10.1029/2004JC002670

Van Wambeke F, Christaki U, Gaudy R (1995) Carbon fluxes from the microbial food web to mesozooplankton. An approach in the surface layer of a pelagic area. Oceanol Acta 19:57-66

Van Wambeke F, Christaki U, Giannakourou A, Moutin T, Souvemerzoglou K (2002) Longitudinal and vertical trends of bacterial limitation by phosphorus and carbon in the Mediterranean Sea. Microb Ecol 43:119-133

Vaqué D, Pace ML, Findlay S, Lints D (1992) Fate of bacterial production in a heterotrophic ecosystem: grazing by protists and metazoans in the Hudson Estuary. Mar Ecol Prog Ser 89:155-163

Vaqué D, Casamayor EO, Gasol JM (2001) Dynamic of whole community bacterial production and grazing losses in seawater incubations as related to the changes in the proportions of bacteria with different DNA content. Aquat Microb Ecol 25:163-177

Vaqué D, Calderón-Paz JI, Guixa-Boixereu N, Pedrós-Alió C (2002) Spatial distribution of microbial biomass and activ-

Editorial responsibility: Karel Šimek, Ceské Budějovice, Czech Republic ity (bacterivory and bacterial production) in the northern Weddell Sea during the austral summer (January 1994). Aquat Microb Ecol 29:107-121

Vázquez-Domínguez E, Peters F, Gasol JM, Vaqué D (1999) Measuring the grazing losses of picoplankton: methodological improvements in the use of fluorescently labeled tracers combined with flow cytometry. Aquat Microb Ecol 20:119-128

> Vázquez-Domínguez E, Gasol JM, Duarte CM, Vaqué D (2005) Growth and grazing losses of prokaryotes in the central Atlantic Ocean. J Plankton Res 27: 1055-1066

Verity PG, Stoecker DK, Sieracki ME, Nelson JR (1993) Grazing, growth and mortality of microzooplankton during the 1989 North Atlantic spring bloom at $47^{\circ} \mathrm{N}, 18^{\circ} \mathrm{W}$. DeepSea Res I 40:1793-1814

Zubkov MV, Sleigh MA, Burkill PH, Leaky RJG (2000a) Bacterial growth and grazing loss in contrasting areas of North and South Atlantic. J Plankton Res 22:685-711

Zubkov MV, Sleigh MA, Burkill PH, Leaky RJG (2000b) Picoplankton community structure on the Atlantic Meridional Transect: a comparison between seasons. Prog Oceanogr 45:369-386

Submitted: September 19, 2007; Accepted: February 13, 2008 Proofs received from author(s): April 17, 2008 